\title{
Genetic Association Analysis for Qualitative Traits in Paprika (Capsicum annuum L.) Genotypes
}

\author{
T. Lakshmi Tirupathamma ${ }^{1}$, L. Naram Naidu ${ }^{2}$, C. Venkata Ramana $^{2 *}$ and K. Sasikala ${ }^{3}$ \\ ${ }^{1}$ Department of Vegetable Science, ${ }^{3}$ Department of Agronomy, College of Horticulture, Dr. \\ Y.S.R. Horticultural University, V.R. Gudem-534 101, India \\ ${ }^{2}$ Horticulture Research Station, Dr.Y.S.R. Horticultural University, Lam Farm, \\ Guntur-522 034, India \\ *Corresponding author
}

\section{A B S T R A C T}

\section{Keywords \\ Capsicum annuит $\mathrm{L}$., Capsaicin, Correlation, Path analysis and carotenoids}

Article Info

Accepted: 08 July 2018 Available Online: 10 August 2018
The present study on inter relationship among seven qualitative traits (ascorbic acid, oleoresin content, capsaicin content, total extractable colour, red carotenoids, yellow carotenoids, total carotenoids) and fruit yield and the direct and indirect effects of qualitative traits on yield of forty four genotypes of paprika (Capsicum annuum L.), revealed that the analysis of variance exhibited significant differences among the genotypes for all the traits. Dry fruit yield per plant showed significant negative association with ascorbic acid content $\left(r_{p}\right.$ and $\left.r_{g}\right)$ and total carotenoids $\left(r_{p}\right.$ and $\left.r_{g}\right)$ at both phenotypic and genotypic level and showed significant and negative with red carotenoids and yellow carotenoids at genotypic level only. The path analysis revealed that ascorbic acid, oleoresin content, capsaicin content and total extractable colour had negative direct effect on yield per plant.

\section{Introduction}

Paprika (Capsicum annuum L.), $2 \mathrm{n}=24$ is one of the important commercial vegetable as well as spice crops grown all over the world. Paprika, a form of chilli is mainly valued for its high colour, low or no pungency and oleoresins. India is one of the leading chilli (Capsicum annuum L.) producing countries of the world. Chilli has diverse utilities as a spice, condiment, culinary supplement, medicine, vegetable and ornamental plant.
Chilli besides imparting pungency and red colour to dishes, is also rich source of vitamin $\mathrm{C}, \mathrm{A}$ and $\mathrm{E}$ and assists in good digestion. The vitamin $C$ content $(150-200 \mathrm{mg} / 100 \mathrm{~g}$ ) of chilli is the highest among all the vegetables. Capsicinoids and carotenoids, the major chemical constituents of chilli fruits add commercial value to the crop. The carotenoids which contribute fruit color act as dietary precursors of vitamin A and among carotenoids 'capsanthin, capsorubin and capsanthin 5, 6-epoxide are responsible for the 
final red color. The nature of pungency has been established as a mixture of seven closely related alkyl vanillylamides, collectively referred as "Capsaicinoids". Among capsiacinoids, capsaicin (8-methyl-Nvanillyl-6-enamide) and dihydrocapsaicin accounts for more than $80 \%$ and determine the pungency (Bosland and Votava, 2000). The degree of pungency varies widely with the genotypes (Kumar et al., 2006). The 'capsaicin' is an alkaloid present in the placenta of the fruit, which can directly scavenge various free radicals (Reddy and Lokesh, 1992; Kogure et al., 2002; Bhattacharya et al., 2010) and has wide applications in the food, medicine and pharmaceutical industries. Chilli has also acquired a great importance because of the presence of 'oleoresin', which permits better color distribution and flavor in foods. The demand for paprika oleoresin as a colouring agent has increased in international market especially in Europe and USA due to ban on artificial colouring substances (Joshi et al., 1995). There is considerable demand for paprika powder in the western countries. There is a great demand for the natural colour from paprika fruits and is used in processed foods in place of synthetic colours.

In view of changing life styles and health concerns quality improvement in crop plants has assumed greatly significance as quality not only improves human health but also adds to farm income. Thus, breeding programmes of late are targeted to improve quality along with yield and tolerance to biotic and abiotic stress.

Knowledge of interrelationship among characters is very important in plant breeding for indirect selection of characters that are not easily measured. For selection, it is essential to know the importance and association of various components and also their association with yield. The correlation coefficient analysis measures the mutual relationship between various characters and determines the component traits on which selection can be relied upon the effect of improvement. Assessing the direct and indirect effects of each component towards yield through path coefficient analysis would help in identifying the component traits contributing to yield. Farhad et al., (2008), Gupta et al., (2009) Sharma et al., (2010), Arup et al., (2011), Kumar et al., (2012), Vikarm et al., (2014), Vijaya et al., (2014), Shiva et al., (2015), Rinchan et al., (2015) and Janaki et al., (2016) were also studied the correlation and path analysis in chilli. But, the availability of data on pungency and colour was important for selection of genotypes from a gene bank for further use in crop improvement.

However, data on pungency and carotenoids among the accessions in Capsicum gene banks are currently limited (Jarret et al., 2003). Thus, the major objective of this study was to determine the nature and degree of association among the yield and qualitative characters and their direct and indirect effects on paprikai yield. Based on this information an effective selection programme can be proposed for the genetic improvement of the crop.

\section{Materials and Methods}

Forty four genotypes of paprika (Table 1) were evaluated in a Randomized Block Design with two replications at Horticultural Research Station, Lam, Guntur, and Andhra Pradesh, India. The site of the experiment at Lam is situated on 160 28' North latitude and 80034' East longitude at an altitude of $31.5 \mathrm{~m}$ above mean sea level which falls under humid tropical climate and the soils of the experimental site were rich black cotton soils. The nursery was raised during first week of August and the seedlings were transplanted at a spacing of $75 \mathrm{~cm} \times 30 \mathrm{~cm}$ in a row of $4 \mathrm{~m}$ length (experimental unit) during first fortnight of September. Each row consisted of 
12 plants, of which five competitive plants were selected at random for collecting the fruit samples to estimate qualitative traits viz. ascorbic acid (mg 100g-1), oleoresin content (\%), capsaicin content $(\%)$, total extractable colour (ASTA units), red carotenoids (\%), yellow carotenoids (\%) and total carotenoids $(\%)$. The red ripen fruits were sun dried and ground in an electronic grinder and passed through a $0.5 \mathrm{~mm}$ sieve and the dry chilli powder was used to measure biochemical constituents whereas mature green fruits were used for estimating the Vitamin ' $\mathrm{C}$ ' content. The following procedures were used for estimating the biochemical constituents.

\section{Ascorbic acid (mg/100g)}

Ascorbic acid content of mature green fruits was estimated by volumetric method (Sadasivam and Balasubramanian, 1987). Dye solution was prepared by dissolving $42 \mathrm{mg}$ of sodium bicarbonate in distilled water taken into $200 \mathrm{ml}$ volumetric flask, to which $52 \mathrm{mg}$ of 2-6 dichlorophenol indophenol was added and the volume was made up to $200 \mathrm{ml}$ with distilled water. Stock solution was prepared by dissolving $100 \mathrm{mg}$ ascorbic acid in $100 \mathrm{ml}$ of $4 \%$ oxalic acid solution and $10 \mathrm{ml}$ of this stock solution was diluted to $100 \mathrm{ml}$ with $4 \%$ oxalic acid to get the working standard of 100 mg per ml.

$5 \mathrm{ml}$ of the working standard solution was pipetted into a $100 \mathrm{ml}$ of conical flask to which $10 \mathrm{ml}$ of $4 \%$ oxalic acid was added. The contents were titrated against the dye $\left(\mathrm{V}_{1} \mathrm{ml}\right)$ to get a pink end point. The chilli sample (5 g) was extracted in $4 \%$ oxalic acid and the volume was made up to $100 \mathrm{ml}$ and the contents were centrifuged. $5 \mathrm{ml}$ of this supernatant was pipetted out, to which $10 \mathrm{ml}$ of 4 per cent oxalic acid was added and titrated against the dye $\left(\mathrm{V}_{2} \mathrm{ml}\right)$. The ascorbic acid content was calculated using the formula given below
Ascorbic acid $(\mathrm{mg} / 100 \mathrm{~g})=\left(0.5 \mathrm{mg} \div \mathrm{V}_{1}\right) \times$ $\left(\mathrm{V}_{2} \div 5 \mathrm{ml}\right) \times(100 \mathrm{ml} \div$ Wt. of the sample $) \times$ 100

\section{Oleoresin content $(\%)$}

The oleoresin content was estimated as per the procedure given by Ranganna (1986). Finely mashed $25 \mathrm{~g}$ chilli powder was transferred to a glass column, which was plugged by cotton plug on its narrow end. A thin layer of cotton was placed over chilli powder in the glass column and $25 \mathrm{ml}$ of acetone was added. After all the acetone was decanted, $25 \mathrm{ml}$ acetone was added each time till a total of $250 \mathrm{ml}$ acetone was added to the contents. After decantatation, the resulting red colored liquid in beaker contains all the principle constituents of chilli. The collected filtrate was transferred to a $250 \mathrm{ml}$ volumetric flask and the volume was made up with acetone. The chilli extract was transferred to a $250 \mathrm{ml}$ beaker of known weight $\left(\mathrm{W}_{1} \mathrm{~g}\right)$ and was kept in water bath at 50- $60 \mathrm{oC}$ for 15-30 minutes so that acetone gets evaporated. Then, weight of the beaker along with contents was recorded as $\mathrm{W}_{2}$ g. The weight of the oleoresin content in the $25 \mathrm{~g}$ chilli powder was calculated and expressed in percentage using the given formula.

Oleoresin content $(\%)=\left(\left(\mathrm{W}_{2}-\mathrm{W}_{1}\right) \div(\right.$ Weight of sample)) $\times 100$

\section{Capsaicin content (SHU)}

The capsaicin content of fruits was estimated by colorimetric method described by Bajaj et al., (1980). 0.5g dry chilli powder was weighed into glass-stoppard test tube; $10 \mathrm{ml}$ dry acetone (add 25g anhydrous sodium sulphate to $500 \mathrm{ml}$ of acetone at least one day before use) was added into the test tube and kept overnight for extraction. Next day samples were centrifuged at $10000 \mathrm{rpm}$ for $10 \mathrm{~min}$ to get clear supernatant. $1 \mathrm{ml}$ of the 
supernatant was taken into a test tube and evaporated to dryness in a hot water bath. Then, the residue was dissolved in $5 \mathrm{ml}$ of $0.4 \%$ of $\mathrm{NaOH}$ solution and $3 \mathrm{ml}$ of $3 \%$ phosphomolybdic acid was added. The contents were shaken and left undisturbed for 1hr. After $1 \mathrm{hr}$, the solution was quickly filtered into centrifuge tubes to remove any floating debris, and then centrifuged at $5000 \mathrm{rpm}$ for $15 \mathrm{~min}$.

The clear blue coloured solution was directly transferred into the cuvette and absorbance was read at $650 \mathrm{~nm}$ along with a reagent blank. A standard graph was prepared using $0-200 \mu \mathrm{g}$ pure capsaicin. Simultaneously 0.2, 0.4, 0.6, 0.8 and $1 \mathrm{ml}$ of working standard solution (stock standard capsaicin solution was prepared by dissolving 50mg capsaicin in $50 \mathrm{ml}$ of $0.4 \% \mathrm{NaOH}$ solution $(1000 \mu \mathrm{g} / \mathrm{ml})$ and working standard solution prepared by diluting the $10 \mathrm{ml}$ of the stock standard to $50 \mathrm{ml}$ with $0.4 \% \mathrm{NaOH}$ solution $(200 \mu \mathrm{g} / \mathrm{ml})$ ) was taken into new test tubes and proceeded as mentioned above. Per cent capsaicin calculated using the formula mentioned below

Capsaicin content $(\%)=(\mu \mathrm{g}$ capsaicin $\times 100 \times$ $100) \div(1000 \times 1000 \times 1 \times 0.5)$

Where, $1 \%=1,60,000$ SHU units

\section{Total extractable colour (ASTA units)}

Total extractable colour of fruits (ASTAAmerican Spice Trade Association units) was estimated as per the procedure given by Rosebrook et al., (1968). 100mg of sieved fine chilli powder was weighed into a volumetric flask. Acetone was added and flask was closed tightly with stopper, then contents were kept for $16 \mathrm{~h}$ at room temperature in dark and shaken intermittently. Solution was filtered using Whatman filter paper and final volume was made up to $100 \mathrm{ml}$. Absorbance of final extract was read at $460 \mathrm{~nm}$ using acetone as blank. ASTA color units were calculated as per the formula given below,

ASTA $=($ Absorbance at $460 \mathrm{~nm} \times 16.4) \div$ (Weight of sample in $\mathrm{g}$ )

\section{Determination of yellow and red fractions in chilli powder}

Total red (CR; capsanthin, capsorubin and capsanthin-5, 6- epoxide) and yellow (CY; zeaxanthin, violaxanthin, antheraxanthin, $\beta$ cryptoxanthin, $\quad \beta$-carotene $\quad$ and cucurbitaxanthin A) carotenoid isochromic fractions were estimated following protocol of spectrophotometric method (Hornero-Mendez and Minguez-Mosquera, 2001). Dried chilli fruits were ground into a fine powder and $100 \mathrm{mg}$ of dried powder was extracted four times with acetone until the complete exhaustion of the color.

The extract was filtered and transferred to $50 \mathrm{ml}$ volumetric flask and the volume was made up with acetone. The samples absorbance was read at two wavelengths i.e., 472 and 508nm using acetone as blank. The red and yellow fractions were calculated using the following formulae.

$\mathrm{CR}(\mu \mathrm{g} / \mathrm{ml})=(\mathrm{A} 508 \times 2144.0)-(\mathrm{A} 472 \times$ $403.0) \div 270.9$

$\mathrm{CY}(\mu \mathrm{g} / \mathrm{ml})=(\mathrm{A} 472 \times 1724.3)-(\mathrm{A} 508 \times$ $2450.1) \div 270.9$

Total colour $=\mathrm{C}^{\mathrm{R}}+\mathrm{C}^{\mathrm{Y}}$

Analysis of variance was carried out as per the procedure given by Panse and Sukhatme (1985). Phenotypic and genotypic correlations were worked out by using formula suggested by Falconer (1964). The direct and indirect effects were computed by using the procedure suggested by Wright (1921) and elaborated by Dewey and Lu (1959). 
Table.1 List of paprika genotypes used in the experiment and their source

\begin{tabular}{|c|c|c|c|c|}
\hline Treatment & $\begin{array}{l}\text { Accession } \\
\text { Number }\end{array}$ & Treatment & Accession Number & Source \\
\hline$T_{1}$ & LCA 445 & $T_{23}$ & LCA 465 & HRS, Lam farm, Guntur \\
\hline $\mathbf{T}_{2}$ & LCA 447 & $\mathrm{~T}_{24}$ & LCA 475 & HRS, Lam farm, Guntur \\
\hline $\mathbf{T}_{3}$ & LCA 439 & $\mathrm{~T}_{25}$ & LCA 488 & HRS, Lam farm, Guntur \\
\hline $\mathbf{T}_{4}$ & LCA 442 & $\mathrm{~T}_{26}$ & LCA 499 & HRS, Lam farm, Guntur \\
\hline$T_{5}$ & LCA 430 & $\mathrm{~T}_{27}$ & LCA 506 & HRS, Lam farm, Guntur \\
\hline$T_{6}$ & LCA 457 & $\mathrm{~T}_{28}$ & LCA 503 & HRS, Lam farm, Guntur \\
\hline $\mathbf{T}_{7}$ & LCA 443 & $\mathrm{~T}_{29}$ & LCA 490 & HRS, Lam farm, Guntur \\
\hline$T_{8}$ & LCA 437 & $\mathrm{~T}_{30}$ & LCA 501 & HRS, Lam farm, Guntur \\
\hline$T_{9}$ & LCA 453 & $\mathrm{~T}_{31}$ & LCA 504 & HRS, Lam farm, Guntur \\
\hline$T_{10}$ & LCA 450 & $\mathrm{~T}_{32}$ & LCA 510 & HRS, Lam farm, Guntur \\
\hline$T_{11}$ & LCA 441 & $\mathrm{~T}_{33}$ & LCA 510 & HRS, Lam farm, Guntur \\
\hline$T_{12}$ & LCA 425 & $\mathrm{~T}_{34}$ & LCA 511 & HRS, Lam farm, Guntur \\
\hline$T_{13}$ & LCA 440 & $\mathrm{~T}_{35}$ & LCA 512 & HRS, Lam farm, Guntur \\
\hline$T_{14}$ & LCA 446 & $\mathrm{~T}_{36}$ & LCA 513 & HRS, Lam farm, Guntur \\
\hline $\mathbf{T}_{15}$ & LCA 470 & $\mathrm{~T}_{37}$ & $\begin{array}{l}\text { Warangal chappatta } \\
\text { single patti }\end{array}$ & HRS, Lam farm, Guntur \\
\hline$T_{16}$ & LCA 436 & $\mathrm{~T}_{38}$ & $\begin{array}{l}\text { Warangal chappatta } \\
\text { double patti }\end{array}$ & HRS, Lam farm, Guntur \\
\hline $\mathbf{T}_{17}$ & LCA 466 & $\mathrm{~T}_{39}$ & Byadagikaddi & HRS, Lam farm, Guntur \\
\hline$T_{18}$ & LCA 472 & $\mathrm{~T}_{40}$ & Byadagidabbi & HRS, Lam farm, Guntur \\
\hline$T_{19}$ & LCA 476 & $\mathrm{~T}_{41}$ & Kt-1 & HRS, Lam farm, Guntur \\
\hline$T_{20}$ & LCA 480 & $\mathrm{~T}_{42}$ & Jangareddygudem local & HRS, Lam farm, Guntur \\
\hline$T_{21}$ & LCA 482 & $\mathrm{~T}_{43}$ & LCA 436 & HRS, Lam farm, Guntur \\
\hline$T_{22}$ & LCA 498 & $\mathrm{~T}_{44}$ & LCA 424 & HRS, Lam farm, Guntur \\
\hline
\end{tabular}

Table.2 Analysis of variance for qualitative characters in paprika (Capsicum annиит L.)

\begin{tabular}{|l|l|l|l|}
\hline \multirow{2}{*}{ Character } & \multicolumn{2}{l}{ Mean sum of squares } & \\
& Replications & Genotypes & Error \\
\hline Ascorbic acid (mg/100g) & 145.89 & $4674.56^{* *}$ & 151.61 \\
\hline Oleoresin content (\%) & 0.53 & $16.66^{* *}$ & 0.66 \\
\hline Capsaicin content (SHU) & 1784670.75 & $36198080.00^{* * *}$ & 157919.3 \\
\hline Total extractable colour (ASTA units) & 22.99 & $2376.67^{* *}$ & 115.58 \\
\hline Red carotenoids (\%) & 0.0005 & $0.02^{* *}$ & 0.0007 \\
\hline Yellow carotenoids (\%) & 0.00004 & $0.015^{* *}$ & 0.0009 \\
\hline Total carotenoids (\%) & 0.0003 & $0.03^{* *}$ & 0.0019 \\
\hline Dry fruit yield per plant (g) & 0.1 & $2316.47^{* *}$ & 178.91 \\
\hline
\end{tabular}

$*$ : Significant at $5 \%$ level; **: Significant at $1 \%$ level. 
Table.3 Phenotypic (above diagonal) and genotypic (below diagonal) correlation coefficients among qualitative characters and yield per plant in paprika (Capsicum annuum L.)

\begin{tabular}{|c|c|c|c|c|c|c|c|c|}
\hline Character & $\begin{array}{l}\text { Ascorbic } \\
\text { acid } \\
(\mathrm{mg} / 100 \mathrm{~g})\end{array}$ & $\begin{array}{l}\text { Oleoresin } \\
\text { content }(\%)\end{array}$ & $\begin{array}{l}\text { Capsaicin } \\
\text { content }(\mathrm{SHU})\end{array}$ & $\begin{array}{l}\text { Total extractable } \\
\text { colour } \\
\text { (ASTA Units) }\end{array}$ & $\begin{array}{l}\text { Red carotenoids } \\
(\%)\end{array}$ & $\begin{array}{l}\text { Yellow } \\
\text { carotenoids (\%) }\end{array}$ & $\begin{array}{l}\text { Total carotenoids } \\
(\%)\end{array}$ & $\begin{array}{l}\text { Dry fruit yield } \\
\text { per plant }(g)\end{array}$ \\
\hline Ascorbic acid (mg /100g) & 1.0000 & 0.0505 & -0.0575 & $-0.3234 * *$ & $0.2261 *$ & 0.0231 & 0.2065 & $-0.3482 * *$ \\
\hline Oleoresin content $(\%)$ & 0.0361 & 1.0000 & -0.1764 & 0.0338 & $-0.2308^{*}$ & 0.0591 & -0.1599 & -0.1793 \\
\hline Capsaicin content (SHU) & -0.0705 & -0.1913 & 1.0000 & -0.1621 & -0.0039 & -0.1024 & -0.0682 & -0.1720 \\
\hline $\begin{array}{l}\text { Total extractable colour (ASTA } \\
\text { Units) }\end{array}$ & $-0.3656 * *$ & 0.0442 & -0.2010 & 1.0000 & 0.0005 & 0.0139 & 0.0105 & -0.0752 \\
\hline Red carotenoids (\%) & $0.2227 *$ & $-0.2477 *$ & -0.0093 & -0.0120 & 1.0000 & -0.1023 & $0.7753 * *$ & -0.2066 \\
\hline Yellow carotenoids (\%) & 0.0254 & 0.0368 & -0.1257 & -0.0064 & -0.1221 & 1.0000 & $0.5484 * *$ & -0.1879 \\
\hline Total carotenoids (\%) & 0.2091 & -0.1950 & -0.0866 & -0.0110 & $0.7835 * *$ & $0.5211 * *$ & 1.0000 & $-0.2956 * *$ \\
\hline Dry fruit yield per plant (g) & $-0.3953^{* *}$ & -0.2040 & -0.1800 & -0.1101 & $-0.2383^{*}$ & $-0.2235^{*}$ & $-0.3469 * *$ & 1.0000 \\
\hline
\end{tabular}

*: Significant at 5 per cent level; **: Significant at 1 per cent level

Table.4 Phenotypic path analysis showing direct (diagonal) and indirect effects of qualitative characters on yield per plant in paprika (Capsicum annuum L.)

\begin{tabular}{|c|c|c|c|c|c|c|c|}
\hline Character & $\begin{array}{l}\text { Ascorbic } \\
\text { acid(mg /100g) }\end{array}$ & $\begin{array}{l}\text { Oleoresin } \\
\text { content }(\%)\end{array}$ & $\begin{array}{l}\text { Capsaicin } \\
\text { content (SHU) }\end{array}$ & $\begin{array}{l}\text { Total extractable } \\
\text { colour (ASTA Units) }\end{array}$ & $\begin{array}{l}\text { Red carotenoids } \\
(\%)\end{array}$ & $\begin{array}{l}\text { Yellow } \\
\text { carotenoids (\%) }\end{array}$ & $\begin{array}{l}\text { Total carotenoids } \\
(\%)\end{array}$ \\
\hline $\begin{array}{l}\text { Ascorbic acid } \\
\text { (mg /100g) }\end{array}$ & $\begin{array}{l}-0.3660 \\
-0.5532\end{array}$ & $\begin{array}{l}-0.0185 \\
-0.0200\end{array}$ & $\begin{array}{l}0.0211 \\
0.0390\end{array}$ & $\begin{array}{l}0.1184 \\
0.2023\end{array}$ & $\begin{array}{l}-0.0827 \\
-0.1232\end{array}$ & $\begin{array}{l}-0.0085 \\
-0.0140\end{array}$ & $\begin{array}{l}-0.0756 \\
-0.1157\end{array}$ \\
\hline Oleoresin content $(\%)$ & $\begin{array}{l}-0.0129 \\
-0.0069\end{array}$ & $\begin{array}{l}-0.2549 \\
-0.1920\end{array}$ & $\begin{array}{l}0.0450 \\
0.0367\end{array}$ & $\begin{array}{l}-0.0086 \\
-0.0085\end{array}$ & $\begin{array}{l}0.0588 \\
0.0476\end{array}$ & $\begin{array}{l}-0.0151 \\
-0.0071\end{array}$ & $\begin{array}{l}0.0408 \\
0.0374\end{array}$ \\
\hline $\begin{array}{l}\text { Capsaicin content } \\
\text { (SHU) }\end{array}$ & $\begin{array}{l}0.0171 \\
0.0271\end{array}$ & $\begin{array}{l}0.0523 \\
0.0735\end{array}$ & $\begin{array}{l}-0.2966 \\
-0.3843\end{array}$ & $\begin{array}{l}0.0481 \\
0.0772\end{array}$ & $\begin{array}{l}0.0012 \\
0.0036\end{array}$ & $\begin{array}{l}0.0304 \\
0.0483\end{array}$ & $\begin{array}{l}0.0202 \\
0.0333\end{array}$ \\
\hline $\begin{array}{l}\text { Total extractable colour } \\
\text { (ASTA Units) }\end{array}$ & $\begin{array}{l}0.0727 \\
0.1622\end{array}$ & $\begin{array}{l}-0.0076 \\
-0.0196\end{array}$ & $\begin{array}{l}0.0365 \\
0.0891\end{array}$ & $\begin{array}{l}-0.2249 \\
-0.4435\end{array}$ & $\begin{array}{l}-0.0001 \\
0.0053\end{array}$ & $\begin{array}{l}-0.0031 \\
0.0029\end{array}$ & $\begin{array}{l}-0.0024 \\
0.0049\end{array}$ \\
\hline Red carotenoids (\%) & $\begin{array}{l}0.7472 \\
-3.3473\end{array}$ & $\begin{array}{l}-0.7629 \\
3.7233\end{array}$ & $\begin{array}{l}-0.0129 \\
0.1400\end{array}$ & $\begin{array}{l}0.0018 \\
0.1810\end{array}$ & $\begin{array}{l}3.3048 \\
-15.0307\end{array}$ & $\begin{array}{l}-0.3382 \\
1.8347\end{array}$ & $\begin{array}{l}2.5622 \\
-11.7773\end{array}$ \\
\hline Yellow carotenoids (\%) & $\begin{array}{l}0.0564 \\
-0.2811\end{array}$ & $\begin{array}{l}0.1440 \\
-0.4074\end{array}$ & $\begin{array}{l}-0.2497 \\
1.3916\end{array}$ & $\begin{array}{l}0.0338 \\
0.0712\end{array}$ & $\begin{array}{l}-0.2495 \\
1.3514\end{array}$ & $\begin{array}{l}2.4377 \\
-11.0709\end{array}$ & $\begin{array}{l}1.3369 \\
-5.7686\end{array}$ \\
\hline Total carotenoids (\%) & $\begin{array}{l}-0.8627 \\
3.6040\end{array}$ & $\begin{array}{l}0.6682 \\
-3.3618\end{array}$ & $\begin{array}{l}0.2847 \\
-1.4922\end{array}$ & $\begin{array}{l}-0.0437 \\
-0.1897\end{array}$ & $\begin{array}{l}-3.2391 \\
13.5077\end{array}$ & $\begin{array}{l}-2.2911 \\
8.9826\end{array}$ & $\begin{array}{l}-4.1778 \\
17.2391\end{array}$ \\
\hline $\begin{array}{l}\text { 'r' with dry fruit yield } \\
\text { per plant }(g)\end{array}$ & $\begin{array}{l}-0.3482 * * \\
-0.3953 * *\end{array}$ & $\begin{array}{l}-0.1793 \\
-0.2040\end{array}$ & $\begin{array}{l}-\mathbf{- 0 . 1 7 2 0} \\
-\mathbf{0 . 1 8 0 0}\end{array}$ & $\begin{array}{l}-0.0752 \\
-0.1101\end{array}$ & $\begin{array}{l}-0.2066 \\
-0.2383\end{array}$ & $\begin{array}{l}-0.1879 \\
-0.2235\end{array}$ & $\begin{array}{l}-0.2956 * * \\
-0.3469 * *\end{array}$ \\
\hline
\end{tabular}

*: Significant at 5 per cent level; **: Significant at 1 per cent level 


\section{Results and Discussion}

Analysis of variance (Table 2) revealed significant differences among the genotypes for all the traits indicating presence of significant variability in the genotypes which can be exploited through selection. These findings were in line with earlier reports of Singh and Singh, (2011) and Krishnamurthy et al., (2013).

The estimates of phenotypic and genotypic correlation coefficient (Table 3 ) revealed that the genotypic correlations were higher than the corresponding phenotypic correlations for most of the characters indicating high heritability of the traits under study as suggested by earlier reports of Farhad et al., (2008), Kumari et al., (2011), Kumar et al., (2012), Vikarm et al., (2014), Shiva et al., (2015) and Janaki et al., (2016). Interrelationship among dry fruit yield plant-1 and ascorbic acid, total carotenoids was significant and negative at both phenotypic and genotypic levels. The genotypic association of red and yellow carotenoids was significant and negative with yield plant-1. These findings suggested that selection for yield plant-1 based on ascorbic acid content, total, red and yellow carotenoids is not beneficial for further crop improvement programme. These results are in accordance with previous reports of Farhad et al., (2008).

The inter relationship among red, yellow and total carotenoids were significant and positive indicating that simultaneous selection of these traits is possible and also suggested that red and yellow carotenoids increases significantly with increase in total carotenoids. These findings are supported by the observations of Naresh et al., (2013). Ascorbic acid content had significant and negative association with total extractable colour at both phenotypic and genotypic levels indicating a significant decrease in ascorbic acid content leads to increase in total extractable colour and viceversa. Oleoresin content showed nonsignificant and positive association with ascorbic acid (0.0505 and 0.0361), total extractable colour (0.0338 and 0.0442) and yellow carotenoids (0.0591 and 0.0368) at both phenotypic and genotypic levels. These results are in line with earlier findings of Gupta et al., (2009). Phenotypic and genotypic association of total extractable colour, red, yellow and total carotenoids with capsaicin content was non- significant and negative.

The path analysis (Table 4) revealed that ascorbic acid, oleoresin content, capsaicin content and total extractable colour had negative direct effect on yield plant- 1 at both phenotypic and genotypic levels indicating that direct selection based on these traits may be not be helpful in evolving high yielding varieties of paprika. These findings are in agreement with reports of Singh et al., (2009), Arup et al., (2011), Vijaya et al., (2014), Rinchan et al., (2015) and Janaki et al., (2016). Red and yellow caroteniods at phenotypic level had high positive direct effect and total carotenoids at genotypic level had high positive direct effect whereas total extractble colour had moderate negative direct effect on yield.

Yield is a complex character, contributed by many traits. In the present study, among the seven traits, ascorbic acid content, oleoresin content, capsaicin content and total extractable colour had negative direct effect at both phenotypic and genotypic level on yield plant-1 indicating that selection could be not effective through this trait for yield improvement. Red and yellow caroteniods at phenotypic level had high positive direct effect and total carotenoids at genotypic level had high positive direct effect indicated that direct selection for yield plant-1 through these traits will be effective. 


\section{Acknowledgements}

I extend my deep sense of reverence and gratitude to Associate Dean, College of Horticultural and Research Institute, Venkataramannagudem, Dr. Y.S.R.H.U for allotting me to HRS, Lam to take up my research work. I am highly thankful to Dr. Y.S.R. Horticultural University, Venkataramannagudem for providing financial assistance in the form of stipend to complete this endeavour.

\section{References}

Arup, C, Amit, B.S, Dai, N and Dutta, S. 2011. Diversity of genetic resources and genetic association analyses of green and dry chillies of eastern India. Chilean Journal of Agricultural Research.71 (3): 350-356.

ASTA. 1986. Official analytical methods of the American spice trade association. $2^{\text {nd }}$ edition, ASTA, Englewood Chiffs, N.I.

Bajaj, K.L., Kaur, G and Sooch, B. 1980 Varietal variation in some important chemical constituents in chilli (Capsicum annuum L.) fruits. Veg. Sci. 7: 48-54.

Bhattacharya, A., Chattopadhyay, A., Mazumdar, D., Chakravarty, A and Pal, S. 2010 Antioxidant constituents and enzyme activities in chilli peppers. Intl. J. Veg. Sci. 16: 201-211.

Bosland, P.W. and Votava, E.J. 2000. Peppers: Vegetable and spice capsicums. CABI Publishing, CAB International, Walingfort, U.K.

Dewey, D.R and Lu, K.H. 1959. A correlation and path analysis of components of crested wheat grass seed production. Agron. J. 51: 515-518.

Farhad, M., Hasanuzzaman, M., Biswas, B.K., Azad, A.K. and Arifuzzaman, M. 2008. Reliability of yield contributing characters for improving yield potential in chilli (Capsicum annum L). Intl. J. Sustain. Crop. Prod. 3:30-38

Gupta, A.M., Singh, D and Kumar, A. 2009 Genetic variability, genetic advance and correlation in chilli (Capsicum annuum L). Indian. J. Agri. Sci. 79(3): 221- 223.

Hornero-Mendez, D. and Minguez-Mosquera, I.M. 2001. Rapid spectrophotometric determination of red and yellow isochromic carotenoid fractions in paprika and red pepper oleoresins. $J$. Agri. Fd. Chem. 49: 3584- 3588.

Janaki, M, Naram, N.L, Venkata, R.C. and Paratpara, R. M. 2016. Genetic interrelationship among qualitative traits and yield in chilli (Capsicum annuum L.) genotypes. International journal of science and nature. 7(2): 310315.

Jarret, R.L., Perkinsb Brian, Fanc, Titan, Princec, Alison, Guthrieb, Kelly, Skoczenski and Brian 2003. Using EIA to screen Capsicum spp. Germplasm for capsaicinoid content. J. $F d$. Comp. Anal. 16: 189-94.

Joshi, S, Verma, T.S. and Thakur, P.C. 1995. Performance of paprika genotypes for export.in Proceedings of National Symposium on Advances in Research and Development in Horticulture for Export, CCSHAU, Hisar, P: 45.

Kogure, K., Goto, S., Nishimura, M., Yasumoto, M., Abe, K. and Ohiwa, L. 2002 Mechanism of potent antiperoxidative effect of capsaicin. Biochimicaet Biophysica Acta. 1573: 84-92.

Krishnamurthy, S.L., Madhavi Reddy, K and Mohan Rao, A. 2013. Genetic variation, path and correlation analysis in crosses among Indian and Taiwan parents in chilli. Veg. sci. 40(2): 210-213.

Kumar, D, Bahadur, V, Rangare S.B and Singh, D. 2012. Genetic variability, heritability and correlation studies in 
chilli (Capsicum annuum L.). Hort Flora Research Spectrum. 1(3): 248252.

Kumar, S., Kumar, R and Singh, J. 2006 Cayenne/ American pepper (Capsicum species). In: Peter KV (ed), Handbook of Herbs and Spices, Vol. 3. Woodhead Publishing, Cambridge, UK, pp. 299312.

Kumari, S.S, Uma Jyothi, K, Chenga Reddy, V, Srihari, D, Siva Sanker, A and Ravi shankar, C, 2011. Character association in paprika (Capsicum annuum L.). Journal of Spices and Aromatic Crops. 20 (1): 43-47.

Naresh, P, Madhavi, R.K, Shivashankara, K.S. and Christopher, G.M. 2013. Genotypic variation for biochemical compounds in capsicum. Indian Journal of Horticulture.70 (1): 43-47.

Panse, V.G. and Sukhatme, P.V. 1985. Statistical methods for agricultural workers. Indian Council Agricultural Research, New Delhi.

Ranganna, S. (1986) Handbook of analysis and quality control for fruits and vegetable products. $2^{\text {nd }}$ edition. p: 259.

Reddy, A.C.P. and Lokesh, B.R. 1992. Changes in catalase and ascorbic acid oxidase activity in response to lead nitrate treatments. Indian J. Pl. Physiol. 34: 143- 146.

Rinchan, D, Madalageri, M.B. and Manjunath, G. 2015. Correlation and path analysis for growth, earliness, yield and quality parameters in chilli (Capsicum annuum L.). Hort Flora Research Spectrum, 4(3): 268-272.

Roserbrook, D.D., Proize, C.C and Barney,
J.E. 1968. Improved method for determination of extractable colour in capsicum spices. J. Assn. Anal. Chem. 51: 637-643.

Sadasivam, S. and Balasubramanian, T. 1987. Practical manual in Biochemistry. TNAU, Coimbatore, p: 14.

Shiva, K.N, Prasath, D, Gobinath, P, Leela, N.K and Zachariah, T.J. 2015. Variability and character association in paprika and paprika alike chillies Journal of Spices and Aromatic Crops. 24 (1): 61-65.

Singh, D.K. and Singh, A. 2011. Assessment of variability parameters and character association for quantitative traits in chilli (Capsicum annuum L.). Prog. Agri. 11(1): 113-116.

Singh, Y, Sharma, M. and Sharma, A. 2009. Genetic variation, association of characters, and their direct and indirect contributions for improvement in chilli peppers. International Journal of Vegetable Science. 15(4): 340-368.

Vijaya, H.M, Mallikarjuna, A.P, Gowda and Nehru, S.D. 2014. Genetic variability, correlation coefficient and path analysis in chilli (Capsicum annuum L.) genotypes. Research in Environment and Life Science. 7(3): 175- 178.

Vikram, A, Warshamana, I.K. and Meenu, G. 2014. Genetic correlation and path coefficient studies on yield and biochemical traits in chilli (Capsicum annuum L) International Journal of Farm Sciences. 4(2): 70-75.

Wright, S. 1921. Correlation and causation. J. Agri. Res. 20: 557-585.

\section{How to cite this article:}

Lakshmi Tirupathamma, T., L. Naram Naidu, C. Venkata Ramana and Sasikala, K. 2018. Genetic Association Analysis for Qualitative Traits in Paprika (Capsicum annиum L.) Genotypes. Int.J.Curr.Microbiol.App.Sci. 7(08): 1273-1281. doi: https://doi.org/10.20546/ijcmas.2018.708.144 